\title{
Where to Go from China 's Milk Industry - Summary of Dairy Policy in Recent Years and Analysis of Its Trend
}

\author{
Qiuping Yong ${ }^{1, a^{*}}$ and Xiaoyan $\mathrm{Wu}^{2, \mathrm{~b}}$ \\ ${ }^{1}$ School of management, Wuhan university of technology, Wuhan, Hubei, 430070, China \\ ${ }^{2}$ School of management, Wuhan university of technology, Wuhan, Hubei, 430070, China \\ a1451175467@qq,com, b1055383683<wxy8801@qq.com
}

Keywords: Domestic milk powder; Dairy policy; Brand; Milk safety incidents; Domestic milk powder

\begin{abstract}
Milk powder industry is an important part of the national economy, a more direct impact on national health and family well-being. This paper summarizes the market situation of China in recent years, combs the dairy policy in recent years, analyzes the industry trend after the New Deal, and puts forward some feasible suggestions to enhance the confidence of the Chinese consumers to the domestic milk powder.
\end{abstract}

\section{Introduction}

The Unreserved Crisis of Confidence. "Alien monk chanting", in the milk powder industry even more so. China's imports of milk powder in 2015 about 300,000 tons, accounting for $40 \%$ of the total market; However, imports of milk powder sales accounted for $60 \%$ [1] of the total sales of the domestic market. In the high-end milk powder market, foreign brands is almost a monopoly. As a powdered milk consumption country, China has many infant milk powder enterprises and brands. But in the same competition with foreign brands, but often at a disadvantage.

Consumers love foreign milk powder plus, while the confidence of domestic milk powder is obviously inadequate.

Drink milk think "source", in a series of milk powder accident, the people even more believe in the quality of origin decision. "China's dairy quality report 2016" shows that in 2015, domestic dairy sampling of the pass rate has been as high as 99.5\%[2].March 7, 2016, at the Fourth Session of the 12th National People's Congress, the Minister of Agriculture Han Changfu indignation and reluctantly said: You buy people things, give people money, people also purchase, This is the stigma of China 's dairy industry[3].Although the problem of foreign milk powder is also a minority, such as the 2008 Mead Johnson melamine, 2009 Dumex suspected to suffer from melamine contamination, the United States in 2011, Abbott, Dumex live insects, 2013 New Zealand Fonterra pollution powder, etc., but people still harsh Of the domestic milk powder to look at the paranoid conviction of foreign milk powder.

Chatter of the "Infighting". Process dispute. In recent years, on the room temperature milk, pasteurized milk, dry process, the wet process is better and worse like the controversy, experts and industry debate, consumers dazzled, helpless, dairy farmers and milk prices are suffering .Large-scale room temperature milk enterprises to reduce costs, with "recovery milk" posing as normal temperature milk, used to replace the high price of dairy farmers from where the acquisition of raw milk. The dairy farmers encounter "sell milk difficult", had to kill the cow. China's dairy industry has been destroyed, large-scale milk enterprises have also become the object of the disaster.

Brand dispute. Brand competition is always there, but in the case of lack of overall consumer confidence, domestic milk powder enterprises in order to crack down on opponents, each other and defame each other. The result is "snipe mussel fight fishermen profit", consumer confidence in domestic milk powder is more inadequate, and more inclined to choose foreign milk powder, the market environment is worsening. 


\section{Analysis of the Policy Situation}

Recent Policy Surveys. Since 2013, China has introduced a series of intensive milk-related laws and regulations and policies. From a macro perspective, the state to promote mergers and acquisitions of domestic milk prices to focus on industry resources, through more stringent qualification to restrict access to industry, change the previous record system for the registration system. From the micro-level, the milk source of the quarantine and milk powder publicity, labeling, nutrition and other aspects of the strict and meticulous provisions, trying to make the whole process of domestic milk can be traced back.

From 2013 to 2016, the state policy on the milk powder industry is in a state of tightening. If the year 2013,2014 to prohibit the import of unregistered foreign enterprises to produce infant formula milk powder, to prohibit the commission processing, OEM and packaging production is a "temporary", then 2015, 2016 to promote domestic legal production qualification Of the dairy enterprises mergers and acquisitions, the implementation of the registration management system is "a permanent cure."

Table 1 Chinese dairy policies from 2013 to 2016

\begin{tabular}{|c|c|c|}
\hline time & Policies and regulations & core content \\
\hline 2013.2 & $\begin{array}{c}\text { Measures for the Administration of } \\
\text { Import and Export Dairy Inspection and } \\
\text { Quarantine Supervision }\end{array}$ & $\begin{array}{l}\text { Infant milk powder will pass the more } \\
\text { stringent quarantine access threshold }\end{array}$ \\
\hline 2013.4 & $\begin{array}{l}\text { "2013 focus on food safety } \\
\text { arrangements" }\end{array}$ & $\begin{array}{c}\text { Establishment of Traceable System of } \\
\text { Quality of Infant Formula Milk Powder by } \\
\text { Technology of Internet of Things }\end{array}$ \\
\hline 2013.6 & $\begin{array}{l}\text { "Improve the quality of milk powder to } \\
\text { boost social consumer confidence } \\
\text { action program" }\end{array}$ & $\begin{array}{l}\text { Organization to carry out infant milk powder } \\
\text { enterprise quality and safety special } \\
\text { inspection, out of a number of } \\
\text { non-compliance enterprise (project) }\end{array}$ \\
\hline 2013.6 & $\begin{array}{c}\text { "On further strengthening the quality of } \\
\text { infant formula milk powder safe } \\
\text { working opinion" }\end{array}$ & $\begin{array}{l}\text { With reference to strict management of drug } \\
\text { management }\end{array}$ \\
\hline 2013.9 & $\begin{array}{l}\text { "On the strengthening of infant formula } \\
\text { milk powder management notice" }\end{array}$ & $\begin{array}{l}\text { Unregistered enterprises outside the infant } \\
\text { formula milk powder is not allowed to } \\
\text { import; prohibit the importation of large } \\
\text { packages of infant formula milk powder to } \\
\text { the domestic packaging }\end{array}$ \\
\hline $\begin{array}{c}2013.1 \\
2\end{array}$ & $\begin{array}{l}\text { "Prohibition on the commission, OEM, } \\
\text { packaging, etc. production of infant } \\
\text { formula milk powder announcement" }\end{array}$ & $\begin{array}{l}\text { Prohibited to commission processing, OEM, } \\
\text { packaging, etc. production of infant formula } \\
\text { milk powder }\end{array}$ \\
\hline 2014.1 & $\begin{array}{c}\text { "Food safety standards for } \\
\text { pre-packaged food labels with special } \\
\text { dietary" }\end{array}$ & $\begin{array}{l}\text { Content claims and functional claims should } \\
\text { not be made for essential ingredients in infant } \\
\text { formula from } 0 \text { to } 6 \text { months of age }\end{array}$ \\
\hline 2014.6 & $\begin{array}{l}\text { "To promote infant milk powder } \\
\text { formula for mergers and acquisitions } \\
\text { business plan" }\end{array}$ & $\begin{array}{l}\text { Promote the legalization of domestic } \\
\text { production of dairy enterprises mergers and } \\
\text { reorganizations, and guide the production } \\
\text { elements to the advantages of enterprises and } \\
\text { focus on regional concentration, and promote } \\
\text { industrial standardization, scale, and modern } \\
\text { development }\end{array}$ \\
\hline 2014.8 & $\begin{array}{c}\text { "Infant formula milk powder } \\
\text { production enterprises food safety } \\
\text { credit file management requirements } \\
\text { (draft)" }\end{array}$ & $\begin{array}{l}\text { Record the information found in the } \\
\text { regulatory issues related to the assessment of } \\
\text { enterprise credit rating, as a basis for } \\
\text { corporate classification and supervision }\end{array}$ \\
\hline 2015.3 & $\begin{array}{c}\text { "Key Work Arrangements for Food } \\
\text { Safety in 2015" }\end{array}$ & $\begin{array}{l}\text { To promote infant milk powder enterprise } \\
\text { mergers and acquisitions; to strengthen infant } \\
\text { milk powder quality and safety supervision, } \\
\text { organization of food safety audit }\end{array}$ \\
\hline
\end{tabular}


Table1.cont

\begin{tabular}{|c|c|c|}
\hline 2015.4 & $\begin{array}{c}\text { "Food Safety Law of the People's } \\
\text { Republic of China" }\end{array}$ & $\begin{array}{c}\text { Prohibited sub-packaging production infant } \\
\text { formula, and the implementation of the } \\
\text { registration management system }\end{array}$ \\
\hline 2015.9 & $\begin{array}{c}\text { "Infant formula milk powder product } \\
\text { formula registration management } \\
\text { approach (Trial) (Draft)" }\end{array}$ & $\begin{array}{c}\text { The preliminary formulation of infant } \\
\text { formula milk powder product formula } \\
\text { registration management, labeling and } \\
\text { instructions and other aspects of the } \\
\text { provisions }\end{array}$ \\
\hline 2015.1 & $\begin{array}{c}\text { "Infant formula milk powder } \\
\text { production enterprise food safety } \\
\text { traceability information record } \\
\text { specification" }\end{array}$ & $\begin{array}{c}\text { Provides the infant formula milk powder } \\
\text { production enterprise food safety traceability } \\
\text { information record specification, including } \\
\text { the product formula information, the raw and } \\
\text { auxiliary material management record, the } \\
\text { production processing record and so on } 8 \\
\text { main records contents }\end{array}$ \\
\hline 2016.6 & $\begin{array}{c}\text { "Infant formula milk powder product } \\
\text { formula registration management } \\
\text { approach" }\end{array}$ & $\begin{array}{c}\text { Limit the amount of the same brand of milk } \\
\text { formula, increase the threshold of } \\
\text { registration, labeling and labeling norms, } \\
\text { such as publicity }\end{array}$ \\
\hline
\end{tabular}

The Innovation of the New Deal .June 6, 2016, the State Food and Drug Administration officially released "infant formula milk powder product formula registration management approach", and in October 1, 2016 will come into effect[4].This was the industry as "the most strict New Deal" milk powder and the previous policy compared to the following prominent new features:

1) set the registration threshold, strict production requirements. The new management system has changed for many years the implementation of the filing system for the registration system, and the registration conditions are very high requirements, "should have the production of infant formula milk powder to adapt to the research and development capabilities, production capacity, testing capacity" In the application for registration of formulations also need to submit the quality and safety standards, including raw materials, product formulations R \& D reports, production processes and product inspection reports, including the relevant materials. Under the New Deal, the original milk powder production on the market will significantly reduce the concentration of the brand will be greatly enhanced.

2) strictly limit the number of recipes, prescribe the formula segment. The new registration management approach expressly provides that "in principle, each enterprise shall not exceed 3 recipe series 9 kinds of product formulations", "The same enterprise to apply for registration of two or more products with the age formula, the product formula should be significantly different "Each formula series can only have infants, older infants and young children of three age segments. Milk prices will officially bid farewell to the past, relying on the number of brands, formula publicity and "change the tank does not change formula" era.

3) to achieve "internal and external governance", express recipe raw materials. Milk powder New Deal is aimed at all the Chinese market, production and sales of infant formula milk powder enterprises, domestic milk prices, foreign milk prices are required to implement a unified standard milk powder with Chinese characteristics, "differentiated" era gone. The New Deal on the name of the milk powder containing animal-derived ingredients, ingredients table in the edible vegetable oil row, the nutritional content of the table items are made strict rules, consumers do not have to false propaganda, numerous nutritious and worry, The distinction between the increasingly clear.

\section{The Trend of Dairy Industry}

Milk Prices Constrained by the Layout of the Industrial Chain. Milk powder New Deal "in principle, each enterprise shall not exceed 3 recipe series 9 kinds of product formulations", registration time limit for January 1, 2018. The current number of milk powder companies still have a lot of inventory, how to deal with inventory to become a major task. Dairy expert Wang Dingmian pointed out that the impact of the New Deal by the dairy industry, the brand regardless of size, 2015 
are busy promotional price cuts, busy product adjustment, busy clearance, the milk industry as a whole decline in profits.[5]

Part of the milk prices are from the "product safety control system" to start, fundamentally deal with the New Deal in food safety requirements: close small, scattered milk sources, investment in new large - scale pasture; From the processing plant to find their own factories and so on. Guangming Dairy Chairman Zhang Chongjian said that the New Deal environment, "the whole industry chain" is the core of dairy quality protection, so bright dairy stresses the core competitiveness of the "product safety control system". June 2015 Bright Dairy acquires TNUVA Group, an Israeli dairy company. In November 2015, Holland acquired a 100-year-old New Zealand plant with an annual output of 81,000 tons and a ranch of 40,000 mu.

Channel to Narrow Down the Purchasing Price of Milk Return to Reason. China's milk powder prices in the world "leading", and the main cause of market price deformity is the price formation mechanism, the channel is to promote the high price of milk powder in China's core factors[6].Although there are high prices of milk powder technology, management and domestic milk prices slightly higher than the foreign and other reasons, but the most important is the domestic milk powder sales channels too much. China's line of milk powder sales channels are generally 5-6 layers, each layer of the channel profits are 10\% -15\%.

Milk powder after the New Deal, imported milk powder was incorporated into the regulatory, cross-border electricity providers, purchasing channel control unprecedented. Large-scale purchasing almost disappeared, overseas direct mail may become the only channel. High-end milk powder on the domestic market price of milk will be weakened, high-priced milk market will reduce the proportion. In addition, many domestic milk enterprises have the layout of foreign milk sources, milk channels to reduce the cost of milk prices will help to return to reason.

Table 2 milk powder price list

\begin{tabular}{|c|c|c|c|c|}
\hline Price & country & $\begin{array}{c}\text { Average } \\
\text { price (yuan / } \\
900 \mathrm{~g})\end{array}$ & country & $\begin{array}{l}\text { Average price } \\
\text { (yuan / 900g) }\end{array}$ \\
\hline \multirow[t]{2}{*}{$<$ 100yuan } & $\begin{array}{c}\text { United } \\
\text { Kingdo } \\
\text { m }\end{array}$ & 90 & $\begin{array}{l}\text { Netherl } \\
\text { ands }\end{array}$ & 90 \\
\hline & Russia & 94 & $\begin{array}{c}\text { German } \\
\mathrm{y}\end{array}$ & 95 \\
\hline \multirow{5}{*}{$\begin{array}{c}100-200 y u \\
\text { an }\end{array}$} & Canada & 105 & Italy & 105 \\
\hline & France & 107 & $\begin{array}{l}\text { Argenti } \\
\text { na }\end{array}$ & 109 \\
\hline & $\begin{array}{c}\text { new } \\
\text { Zealand }\end{array}$ & 126 & $\begin{array}{l}\text { South } \\
\text { Africa }\end{array}$ & 130 \\
\hline & $\begin{array}{c}\text { Austral } \\
\text { ia }\end{array}$ & 136 & Brazil & 146 \\
\hline & Japan & 147 & $\begin{array}{l}\text { United } \\
\text { States }\end{array}$ & 163 \\
\hline \multicolumn{5}{|c|}{ World milk powder average price: 120 or so $\quad$ Chinese milk } \\
\hline
\end{tabular}

Transformation of Another New Machine to Open up Market Segments. Milk powder Although the New Deal has landed, but there are uncertain prospects, the direction of the problem is unclear, many milk prices are still exploring and adapting. At the same time, the New Deal under the formula, the infant milk powder market regulation unprecedented strict, many milk prices have been accelerating the layout of the adult milk powder market, in order to digest production capacity and to seek new growth points.2016, the number of brand milk powder in more than 300 brands, 
adding $60 \%$.Diversification has become a breakthrough in the dilemma of milk to regain the strategic choice of new life, but also affected by the New Deal the largest milk brands of small and medium enterprises straw.

December 11, 2016, Wyeth milk powder held in Shanghai since the New Deal's first new conference, launched the domestic first ultra-high-end positioning of pregnant women milk powder rhyme. Nestle, Abbott, the United States-good children, Yili, Mengniu, Feihe, and other brands, are in the introduction of high-end pregnant milk powder products. At present, China's milk market has more than one billion market size, the future is still in the rising stage.

Price War Is Difficult to Avoid Upstream Dairy Farmers Are More Injured. In 2016 the domestic milk powder market is bleak, in May the milk powder price compared to 2013 reduced $58.2 \%$, the domestic milk powder price is higher than the imported milk powder price $67 \%$.On the one hand, the domestic dilemma facing the weak demand, but on the other hand there are dangers of low-cost imports of dairy products. In the 7th China Dairy Conference and 2016 China Dairy Exhibition, China Dairy Association, said Gao Hongbin, in March 2016, the domestic dairy farming losses have reached 51\%, 5.8\% higher than last year[7].

The implementation of the registration system, may make the milk industry pains more pain. With the sharp reduction in market brands, milk prices will be eager to deal with the huge inventory, while reducing prices to remove inventory is the most used means. Lower prices for consumers is welfare, but the doldrums in 2016 for milk prices is undoubtedly worse. In July 2016, the first loss of modern animal husbandry was forced to stop cattle loss, high-quality milk powder was powder. December 2016 financial data, Mengniu Dairy fell 4.67\%, this year's performance may also have a larger loss. With the dairy farmers, milk prices continued to fall, down milk may be even worse. An industry source, in 2016 by the decline in raw milk prices, a lot of farming enterprises to deal with part of the cows, the total amount of about 800000 -100 million.

No-name Exit, Channel Sink. Milk powder registration system policy with the milk prices of a strict formula, in principle, cannot exceed 3 formula series. At present, China (online and offline) a total of about 3,000 brands, $80 \%$ of the brand is expected to be eliminated, only $500-600$ brands will be able to "survive."

At present, foreign milk powder occupy the high-end market share of about $60 \%-70 \%$, its high-end high-priced strategy in the short term is unlikely to make changes. When the original domestic small and medium-sized brands and OEM milk powder was forced to withdraw, the three or four lines of urban and rural markets will become the new domestic milk prices Blue Ocean, to provide 30 billion per year or so of the market. In the milk under the New Deal, the domestic milk powder distribution channels should continue to sink. With the stimulation of the two child policy, the low cost of raising three or four lines of urban and rural areas will have more children born, a huge demand for milk powder and improve the standard of living will attract domestic and foreign milk powder companies compete for this part of the market.

\section{Suggestions to Improve the Chinese Dairy Industry}

Quality Is of the Utmost Importance. "Sea Amoy hot" core reason "Shopping fever" behind, is still lack of consumer confidence in domestic milk powder quality. Domestic milk powder self-salvation the only way out is to unswervingly enhance the quality, reduce or even eliminate domestic milk powder accident. Any accident on the domestic milk powder is a devastating blow, consumers will consume the domestic milk powder only trust and confidence. China's milk prices must establish a "quality is greater than the day" awareness, and truly enhance the quality and build brand as a strategic task and objectives to achieve. Ignoring quality, the pursuit of profits may be temporary benefits, but will ruin the future of enterprises and the future of China's dairy industry. Strict quality control is not just milk powder business, it is the responsibility of national regulatory authorities.

Take the International Road. November 11, 2016, by the Xinhua News Agency, "Financial State Week", the think tank launched, the State Food and Drug Administration, the Ministry of Industry, dairy experts, dairy companies, representatives of the media and other representatives to 
participate in the discussion, "China's international dairy industry Opportunities and Challenges"[8].From the current perspective, China's dairy industry, "domestic" is still a long way to go, the internationalization of the road is far away. But to really enhance themselves and win the trust of consumers, the Chinese dairy industry must be determined in the international. Fei Lu Dairy Vice President Lu believes that "China's milk prices to break through the bottleneck, international cooperation is a better path. "Internationalization will help Chinese dairy enterprises to open up more overseas, in the international market competition and cooperation will help to understand the operation of international brands, but also to speed up China's milk prices in line with international standards, but also conducive to quality Of the upgrade.

Upgrade by Long-Term. In recent years, frequent milk powder incident does not prove that China's dairy industry is uncertain, in fact, developed countries have also appeared in a series of milk powder problems. In 1955 Japan Morinaga dairy milk powder incident caused 130 infant deaths, 12344 children poisoning malignant events[9], in 2003 the United States of Heinz milk powder suspected with infant death in Israel was recalled, Belgium, the Netherlands, France, Germany and other countries dairy products were Detection of carcinogenic substances "dioxin", the outbreak of the biggest ever food safety problems. From 2002 to 2009, the United States is still an average of 1-2 a year of toxic milk powder.

Now these countries to enhance the quality of milk powder, and they experience the safety of milk powder is directly related. China's dairy quality problem is a difficult to avoid, take time to overcome the problem. The Chinese government and milk prices must be the milk powder accident at home and abroad as a lesson, firm conviction, with long-term efforts to pursue quality improvement.

Improve the Regulatory System. Consumer confidence in domestic milk powder, one of the reasons is the disappointment of domestic dairy regulation. Improve the regulatory system, should be led by the Government, the introduction of consumers, associations involved.

In order to effectively rebuild the consumer confidence in the domestic production of milk powder, the CPPCC National Committee member Yung Wing-chi made four recommendations:1, the establishment of one-stop source of traceability, supervision, testing and enforcement mechanisms. 2, to promote universal monitoring, strengthen the promotion of food safety messages.3, open the list of illegal enterprises, and attention to media supervision of dairy enterprises. 4, to strengthen supervision of the Chinese Consumers Association power.

Reconstructing the Interest Mechanism. Dairy farmers and milk prices are essentially the fate of the community, the enthusiasm of dairy farmers need to improve milk prices, and the stability of milk prices cannot do without the support of dairy farmers. In 2014, 2016 dairy slump, many dairy farmers were forced to slaughter cattle down the milk, the cost of 2-3 million a cow was slaughtered as beef cattle, the interests of great damage, enthusiasm is very affected.

The establishment of dairy farmers - milk enterprises to share the interests of the Chinese dairy industry to enhance the quality of order to ensure long-term solution. December 6, 2016, Hebei Provincial Department of Agriculture and all the dairy processing enterprises in the province signed the "perfect long-term mechanism of dairy interests cooperation memorandum"[10], covering 12 key areas. All levels of government play an important role in guiding, supporting and supervising, and ensuring the stability of the upstream supply chain will directly affect the trend and future of Chinese dairy industry.

\section{Conflict of Interest}

The author confirms that this article content has no conflict of interest.

\section{References}

[1] Feng Kai, Liu Li. Under the new deal the reality of the plight of the milk powder companies and breaking the road [J]. Dairy and human, 2016 (2): 20-29. 
[2] China Dairy Association. "China dairy quality report 2016" [Z].2016-08-18.

[3] Xu Han Changfu xueya. Adjust the structure to the way to accelerate the development of modern agriculture and rural work "communication" and "communication" [J]. Work in rural areas, 2016 (6): 10-13.

[4] Wang Lin. A new frequency: milk powder more than 1000 brands face out of [J]. "Agricultural product market weekly", 2016 (4): 24-25.

[5] Changjiang Securities. The milk industry: demand rise into the cycle, the registration system to supply contraction and clearing pattern of [EB/OL].http://www.howbuy.com/news/2016-06-08/4497628.html, 2016-06-08.

[6] Had Shiqi. China Dairy Development -- the seventh Chinese have a brilliant future dairy conference and the 2016 Chinese dairy industry exhibition opened in Qingdao [J]. "Agricultural product market weekly", 2016 (23): 16-18.

[7] Star. Opportunities and challenges of Chinese enterprises internationalization [J]. Zhongguancun, 2016 (8): 32-35.

[8] Zhou ang.50 years ago, Japan's tainted milk powder incident: 130 infants died within a year [J]. "Consultation Forum", 2013 (4): 52-54.

[9] Wu man. Hebei province to develop a "memorandum of cooperation to improve the long-term mechanism of the interests of dairy industry" [J]. "Northern animal husbandry", 2015 (16): 7-7. 